\title{
Bacillus bogoriensis sp. nov., a novel alkaliphilic, halotolerant bacterium isolated from a Kenyan soda lake
}

Correspondence

Rajni Hatti-Kaul

Rajni.Hatti-Kaul@biotek.lu.se

\author{
Virginia A. Vargas, ${ }^{1,2}$ Osvaldo D. Delgado, ${ }^{1} \dagger$ Rajni Hatti-Kaul ${ }^{1}$ \\ and Bo Mattiasson ${ }^{1}$
}

\author{
${ }^{1}$ Department of Biotechnology, Center for Chemistry and Chemical Engineering, Lund \\ University, PO Box 124, SE-22 100 Lund, Sweden \\ ${ }^{2}$ Centro de Biotecnología, Facultad de Ciencias y Tecnología, Universidad Mayor de San \\ Simón, Cochabamba, Bolivia
}

\begin{abstract}
Strain LBB3 $^{\top}$ isolated from Bogoria soda lake in Kenya is an alkaliphilic, Gram-positive, strictly aerobic, non-motile, spore-forming bacterium. It was identified as a member of the genus Bacillus on the basis of phenotypic and phylogenetic analyses. The organism grows optimally at $37^{\circ} \mathrm{C}$ and $\mathrm{pH}$ 10. The $\mathrm{G}+\mathrm{C}$ content of the genomic DNA is $37.5 \mathrm{~mol} \%$. $16 \mathrm{~S}$ rRNA gene sequence analysis showed 95 and $96 \%$ sequence similarity with Bacillus pseudofirmus (DSM 8715 ${ }^{\top}$ ) and Bacillus alcalophilus (DSM $485^{\top}$ ), respectively. Furthermore, DNA-DNA hybridization against these two Bacillus species showed 39.0 and $55.5 \%$ similarity, respectively. Based on our observations, strain $\mathrm{LBB}^{\top}$ is proposed to represent a novel species of the genus Bacillus, for which the name Bacillus bogoriensis sp. nov. is proposed. The type strain of $B$. bogoriensis is LBB3 $^{\top}$ ( $=$ ATCC BAA-922 ${ }^{\top}=$ LMG $22234^{\top}$ ).
\end{abstract}

The genus Bacillus comprises a vast diversity of physiological types. The G+C content (32-69 mol\%) of the known Bacillus species, as well as DNA-DNA hybridization experiments, has revealed the heterogeneity of the genus. Phenetic diversity of alkaliphilic Bacillus strains has been studied, and so far 11 alkaliphilic Bacillus strains have been isolated and identified (Fritze et al., 1990; Nielsen et al., 1994, 1995). Soda lakes contain dense populations of aerobic organotrophic and alkaliphilic bacteria. Some of these bacteria are believed to have biotechnological potential as a source of alkali-stable enzymes (Gessesse \& Gashe, 1997; Martins et al., 2001).

Strain $\mathrm{LBB}^{\mathrm{T}}$ was recovered from liquid samples collected from Lake Bogoria, Kenya in a screening medium for lipolytic micro-organisms (Vargas et al., 2004), composed of $3 \%(\mathrm{v} / \mathrm{v})$ olive oil and basal salts (w/v) $\left[0.08 \% \mathrm{~K}_{2} \mathrm{HPO}_{4}\right.$, $0.06 \% \mathrm{KH}_{2} \mathrm{PO}_{4}, 0.1 \%\left(\mathrm{NH}_{4}\right)_{2} \mathrm{SO}_{4}, 0.02 \% \mathrm{MgSO}_{4} .7 \mathrm{H}_{2} \mathrm{O}$,

Published online ahead of print on 5 November 2004 as DOI 10.1099/ ijs.0.63318-0.

tPresent address: PROIMI - CONICET, Av. Belgrano y Pasaje Caseros, 4000 San Miguel de Tucumán, Argentina.

The GenBank/EMBL/DDBJ accession number for the 16S rRNA gene sequence of $\mathrm{LBB}^{\top}$ is $\mathrm{AY} 376312$.

A phylogenetic tree and electron micrographs are available as supplementary material in IJSEM Online. $\left.0.005 \% \mathrm{CaCl}_{2} \cdot 2 \mathrm{H}_{2} \mathrm{O}, 0.3 \% \mathrm{NaCl}, 0.0001 \% \mathrm{FeCl}_{3}\right]$. It was grown at $37^{\circ} \mathrm{C}$ and $\mathrm{pH} 10$ on an orbital shaker at 200 r.p.m. Cell morphology was examined using a Nikon Optiphot-2 microscope at $1000 \times$ magnification. Bacterial size was determined in living cell preparations. Cells were harvested from liquid cultures, washed twice with water and dehydrated through a graded series of ethanol and isopropyl alcohol. Cells were then mounted on $12 \mathrm{~mm}$ cover slips, dried in a vacuum desiccator overnight and then goldpalladium (80/20) coated. Biochemical characteristics were screened by using the API $20 \mathrm{E}$ system (bioMérieux) according to Logan \& Berkeley (1984). Sugar assimilation was determined by using the API 50 CHB system.

Genomic DNA was extracted and purified according to Marmur (1961), and its purity was assessed from the $A_{260} / A_{280}$ and $A_{260} / A_{230}$ ratios (Johnson, 1994). Universal primers were used to amplify $16 \mathrm{~S}$ rRNA genes $(8-27 \mathrm{~F}$, AGAGTTTGATCCTGGCTCAG; 1422R, GGTTACCTTGTTACGACTT) (Weisburg et al., 1991). PCR products were purified using the QIA quick PCR Purification kit (Qiagen) and then resuspended in a final volume of $40 \mu \mathrm{l}$. DNA sequencing on both strands was performed by using the dideoxy chain-termination method with an $\mathrm{ABI}$ Prism 3100 DNA Analyzer, using an ABI Prism Big Dye Terminator Cycle Sequencing Ready Reaction kit (PE Applied Biosystems) according to the manufacturer's protocol. GenBank and RDP databases were used to search for 16S rRNA gene sequence similarities (Maidak 
Table 1. Phenotypic characteristics that differentiate Bacillus bogoriensis $\mathrm{LBB}^{\top}{ }^{\mathrm{f}}$ from phylogenetically related species

Species: 1, Bacillus bogoriensis LBB3 ${ }^{\mathrm{T}} ; 2$, B. alcalophilus DSM $485^{\mathrm{T}} ; 3$, B. pseudofirmus DSM $8715^{\mathrm{T}} ; 4$, B. agaradhaerens DSM $8721^{\mathrm{T}}$; 5 , B. clarkii DSM $8720^{\mathrm{T}}$; 6, B. pseudalcaliphilus DSM $8725^{\mathrm{T}}$; 7, B. halodurans DSM $497^{\mathrm{T}}$. All data are from Nielsen et al. (1995) except those for B. bogoriensis (this study). All strains are rod-shaped, and negative for erythritol, L-xylose, adonitol, dulcitol, inulin, D-fucose and L-fucose utilization. All strains utilize L-arabinose, D-xylose, fructose, salicin, cellobiose, maltose, trehalose, gentiobiose, starch, glycogen and ribose.

\begin{tabular}{|c|c|c|c|c|c|c|c|}
\hline Characteristic & 1 & 2 & 3 & 4 & 5 & 6 & 7 \\
\hline \multicolumn{8}{|l|}{ Growth at: } \\
\hline $10^{\circ} \mathrm{C}$ & + & + & + & + & - & + & - \\
\hline $45^{\circ} \mathrm{C}$ & + & - & + & + & + & - & + \\
\hline $55^{\circ} \mathrm{C}$ & - & - & - & - & - & - & + \\
\hline pH optimum & 10 & 9 & 9 & $>10$ & $>10$ & 10 & $9-10$ \\
\hline \multicolumn{8}{|l|}{ Growth with: } \\
\hline $\mathrm{NaCl}(10 \%)$ & + & - & + & + & + & + & + \\
\hline $\mathrm{NaCl}(16 \%)$ & - & - & + & + & + & - & - \\
\hline \multicolumn{8}{|l|}{ Colony morphology } \\
\hline Pigmentation & Cream-yellow & White & Yellow & White & Cream-white & White & White \\
\hline Margins & Entire & Entire & Irregular & Filamentous & Entire & Undulate & Filamentous \\
\hline Cell size $(\mu \mathrm{m})$ & $0 \cdot 3-0 \cdot 4 \times$ & $0 \cdot 5-0 \cdot 7 \times$ & $0 \cdot 6-0 \cdot 8 \times$ & $0.5-0.6 \times$ & $0 \cdot 6-0 \cdot 7 \times$ & $0 \cdot 5-0 \cdot 6 \times$ & $0 \cdot 5-0 \cdot 6 \times$ \\
\hline & $2 \cdot 0-3 \cdot 5$ & $3 \cdot 0-5 \cdot 0$ & $2 \cdot 0-4 \cdot 0$ & $2 \cdot 0-5 \cdot 0$ & $2 \cdot 0-5 \cdot 0$ & $2 \cdot 0-4 \cdot 0$ & $3 \cdot 0-4 \cdot 0$ \\
\hline $\mathrm{G}+\mathrm{C}$ content $(\mathrm{mol} \%)$ & $37 \cdot 5$ & $36 \cdot 2-38 \cdot 4$ & $39 \cdot 0-40 \cdot 8$ & $39 \cdot 3-39 \cdot 5$ & $42 \cdot 4-43 \cdot 0$ & $38 \cdot 2-39 \cdot 0$ & $42 \cdot 1-43 \cdot 9$ \\
\hline Starch hydrolysis & + & + & + & + & - & + & + \\
\hline Gelatin hydrolysis & - & + & + & + & + & + & + \\
\hline Nitrate reduction & - & $+\dagger$ & - & + & + & - & $+\dagger$ \\
\hline \multicolumn{8}{|l|}{ Growth on: } \\
\hline Glucose & - & + & + & + & $-*$ & + & + \\
\hline Sucrose & - & + & + & + & $-{ }^{\star}$ & + & + \\
\hline Amygdalin & - & + & + & + & $-{ }^{*}$ & + & + \\
\hline Inositol & - & + & $+\dagger$ & - & $-^{*}$ & - & + \\
\hline Lactose & + & + & - & + & $-^{\star}$ & + & + \\
\hline Mannose & + & + & + & + & $-^{\star}$ & - & + \\
\hline Rhamnose & + & + & - & + & $-^{*}$ & + & + \\
\hline Melibiose & - & + & - & + & $-^{\star}$ & - & + \\
\hline Lactose & + & + & - & + & $-{ }^{\star}$ & + & + \\
\hline Raffinose & + & + & - & + & $-{ }^{\star}$ & - & + \\
\hline$N$-Acetylglucosamine & + & + & + & + & $-{ }^{*}$ & - & + \\
\hline Methyl $\beta$-xyloside & - & + & - & - & $-{ }^{*}$ & + & + \\
\hline Galactose & - & + & $+\dagger$ & + & $-{ }^{\star}$ & + & + \\
\hline Sorbitol & - & - & - & + & $-{ }^{\star}$ & - & - \\
\hline Methyl $\alpha$-D-mannoside & - & + & - & + & $-{ }^{*}$ & - & - \\
\hline Methyl $\alpha$-D-glucoside & - & + & + & + & $-{ }^{\star}$ & + & + \\
\hline Melezitose & - & + & - & + & $-^{\star}$ & - & + \\
\hline Xylitol & - & - & $+\dagger$ & - & $-^{\star}$ & - & + \\
\hline D-Turanose & - & + & + & + & $-^{\star}$ & + & + \\
\hline D-Lyxose & - & + & + & + & $-^{\star}$ & + & + \\
\hline D-Tagatose & - & + & - & + & $-^{\star}$ & + & $+\dagger$ \\
\hline Gluconate & - & - & + & - & $-^{\star}$ & + & + \\
\hline 2-Ketogluconate & - & - & $+\dagger$ & + & $-{ }^{*}$ & + & + \\
\hline D-Arabitol & - & + & + & + & $-{ }^{\star}$ & - & + \\
\hline
\end{tabular}

${ }^{*}$ No growth is observed in minimal medium for carbohydrate utilization at $\mathrm{pH} 10$.

†Weakly positive.

et al., 2000). A $16 \mathrm{~S}$ rRNA gene sequence analysis was performed with the aid of the DNAMAN 4.03 software package by using the neighbour-joining method and the
Jukes-Cantor distance correction matrix method (Saitou \& Nei, 1987). Determination of peptidoglycan type was carried out as described previously (Schleifer \& Kandler, 
1972; Schleifer, 1985), with the modification that TLC on cellulose was used instead of paper chromatography.

Genomic G $+\mathrm{C}$ content (mol\%) and DNA-DNA hybridization were determined by the Deutsche Sammlung von Mikroorganismen und Zellkulturen (DSMZ, Braunschweig, Germany). DNA was isolated by chromatography on hydroxyapatite by the procedure of Cashion et al. (1997). G+C content was calculated according to the method of Mesbah et al. (1989). DNA-DNA hybridization was carried out as described by De Ley et al. (1970) with the modifications described by Huss et al. (1983) and Escara \& Hutton (1980) using a Gilford System model 2600 spectrophotometer equipped with a Gilford model 2527-R thermoprogrammer and plotter. Renaturation rates were computed with the TRANSFER.BAS program described by Jahnke (1992).

An almost-complete 16S rRNA gene sequence was determined for strain $\mathrm{LBB}^{\mathrm{T}}$ and compared with other available sequences in the GenBank and RDP databases (Fig. A, available as supplementary material in IJSEM Online). This analysis placed the novel strain in the family Bacillaceae, with the closest related micro-organisms being Bacillus pseudofirmus (DSM 8715 ${ }^{\mathrm{T}}$ ) and Bacillus alcalophilus (DSM $485^{\mathrm{T}}$ ), bearing 95 and $96 \%$ sequence similarity, respectively.

A comparison of the morphological and taxonomic characteristics of strain $\mathrm{LBB}^{\mathrm{T}}{ }^{\mathrm{T}}$ with those of phylogenetically related species is shown in Table 1. Strain LBB3 $^{\mathrm{T}}$ produces cream-yellow, circular, convex, smooth, entire, opaque colonies that are 5-6 $\mathrm{mm}$ in diameter after $48 \mathrm{~h}$ incubation at $37^{\circ} \mathrm{C}$. It is Gram-positive. Microscopic examination showed the cells to be spore-forming and non-motile rods that are $0 \cdot 3-0 \cdot 4 \mu \mathrm{m}$ wide and $2 \cdot 0-3 \cdot 5 \mu \mathrm{m}$ long. In unstained preparations, cells occur singly, in pairs and in irregular clumps (Fig. B, available as supplementary material in IJSEM Online).

Strain $\mathrm{LBB}^{\mathrm{T}}$ revealed uniform growth in the liquid medium, which led to a turbid culture broth and no formation of pellicles. It was strictly aerobic and mesophilic, exhibiting growth between 10 and $40{ }^{\circ} \mathrm{C}$, with an optimum at $37^{\circ} \mathrm{C}$. Growth was supported between $\mathrm{pH} 8$ and 11 , with an optimum at $\mathrm{pH} 10$, and with up to $2 \mathrm{M} \mathrm{NaCl}$ in the medium. Analysis of the cell wall showed the presence of peptidoglycan type A $4 \beta \mathrm{L}$-Orn-D-Asp. This pattern is typical for members of the genus Bacillus and related genera.

As shown in Table 1 , the $\mathrm{G}+\mathrm{C}$ content of strain $\mathrm{LBB}^{\mathrm{T}}$ is $37.5 \mathrm{~mol} \%$. This value lies within the range for low $\mathrm{G}+\mathrm{C}$ content Gram-positive bacteria. DNA-DNA hybridization analysis revealed $39.0 \%$ similarity to $B$. pseudofirmus DSM $8715^{\mathrm{T}}$ and $55 \cdot 5 \%$ similarity to B. alcalophilus DSM $485^{\mathrm{T}}$. These values for hybridization are significantly lower than the recommended threshold value of at least $70 \%$ accepted as the definition of a novel species (Wayne et al., 1987), hence supporting the distinct position of strain $\mathrm{LBB}^{\mathrm{T}}$ in the genus Bacillus. Differences in 16S rRNA gene sequence identity of $3 \%$ and the $\mathrm{G}+\mathrm{C}$ content justify the description of a novel Bacillus species to accommodate strain LBB3 ${ }^{\mathrm{T}}$.

Based on the analyses of morphological, physiological and phylogenetic traits, we propose strain $\mathrm{LBB}^{\mathrm{T}}$ to be a novel alkaliphilic, halotolerant species of the genus Bacillus, for which the name Bacillus bogoriensis sp. nov. is proposed.

\section{Description of Bacillus bogoriensis sp. nov.}

Bacillus bogoriensis (bo.gor.i.en'sis. N.L. adj. bogoriensis pertaining to Lake Bogoria, a soda lake in Kenya).

Cells are rod-shaped $(0 \cdot 3-0 \cdot 4 \times 2 \cdot 0-3 \cdot 5 \mu \mathrm{m})$, Gram-positive, spore-forming and non-motile. Catalase-positive and urease-negative. Nitrate is not reduced to nitrite. Strictly aerobic. Optimal growth occurs aerobically at $37^{\circ} \mathrm{C}$ (range $10-40{ }^{\circ} \mathrm{C}$ ), $\mathrm{pH} 10$ (range $8-11$ ) and maximum salt tolerance of $2 \mathrm{M} \mathrm{NaCl}$. Heterotrophic; utilizes rhamnose, sucrose, L-arabinose, D-xylose, fructose, mannose, amygdalin, salicin, cellobiose, maltose, arbutin, aesculin, lactose, trehalose, gentiobiose, starch, glycogen, glycerol, ribose, raffinose, $\mathrm{N}$-acetylglucosamine and 5-ketogluconate. Does not grow on mannitol, erythritol, D-arabinose, L-xylose, adonitol, methyl $\beta$-xyloside, D-glucose, galactose, melibiose, L-sorbose, dulcitol, inositol, sorbitol, methyl $\alpha$-D-mannoside, methyl $\alpha$-D-glucoside, inulin, melezitose, xylitol, D-turanose, D-lyxose, D-tagatose, D-fucose, L-fucose, D-arabitol, gluconate or 2-ketogluconate. DNA G + C content is $37.5 \mathrm{~mol} \%$ (determined by HPLC).

The type strain is $\mathrm{LBB}^{\mathrm{T}}\left(=\mathrm{ATCC}\right.$ BAA $-922^{\mathrm{T}}=\mathrm{LMG}$ $\left.22234^{\mathrm{T}}\right)$.

\section{Acknowledgements}

This work was supported by a grant from the Department for Research Cooperation (SAREC) within the Swedish International Development Cooperation Agency (Sida).

\section{References}

Cashion, P., Holder-Franklin, M. A., McCully, J. \& Franklin, M. (1997). A rapid method for the base ratio determination of bacterial DNA. Anal Biochem 81, 461-466.

De Ley, J., Cattoir, H. \& Reynaerts, A. (1970). The quantitative measurement of DNA hybridization from renaturation rates. Eur J Biochem 12, 133-142.

Escara, J. F. \& Hutton, J. R. (1980). Thermal stability and renaturation of DNA in dimethyl sulfoxide solutions: acceleration of renaturation rate. Biopolymers 19, 1315-1327.

Fritze, D., Flossdorf, J. \& Claus, D. (1990). Taxonomy of alkaliphilic Bacillus strains. Int J Syst Bacteriol 40, 92-97.

Gessesse, A. \& Gashe, B. A. (1997). Production of alkaline protease by an alkaliphilic bacteria isolated from an alkaline soda lake. Biotechnol Lett 19, 479-481.

Huss, V. A. R., Festl, H. \& Schleifer, K. H. (1983). Studies on the spectrometric determination of DNA hybridization from renaturation rates. Syst Appl Microbiol 4, 184-192. 
Jahnke, K. D. (1992). Basic computer program for evaluation of spectroscopic DNA renaturation data from GILFORD System 2600 spectrometer on a PC/XT/AT type personal computer. J Microbiol Methods 15, 61-73.

Johnson, J. L. (1994). Similarity analysis of DNAs. In Methods for General and Molecular Bacteriology, pp. 655-682. Edited by P. Gerhardt, R. G. E. Murray, W. A. Wood \& N. R. Krieg. Washington, DC: American Society for Microbiology.

Logan, N. A. \& Berkeley, R. C. (1984). Identification of Bacillus strains using the API system. J Gen Microbiol 130, 1871-1882.

Maidak, B. L., Cole, J. R., Lilburn, T. G. \& 9 other authors (2000). The RDP (Ribosomal Database Project) continues. Nucleic Acids Res 28, 173-174.

Marmur, J. (1961). A procedure for the isolation of deoxyribonucleic acid from microorganisms. J Mol Biol 3, 208-218.

Martins, R. F., Davids, W., Abu Al-Soud, W., Levander, F., Rådström, P. \& Hatti-Kaul, R. (2001). Starch-hydrolyzing bacteria from Ethiopian soda lakes. Extremophiles 5, 135-144.

Mesbah, M., Premachandran, U. \& Whitman, W. B. (1989). Precise measurement of the $\mathrm{G}+\mathrm{C}$ content of deoxyribonucleic acid by highperformance liquid chromatography. Int J Syst Bacteriol 39, 159-167.

Nielsen, P., Rainey, F. A., Outtrup, H., Priest, F. G. \& Fritze, D. (1994). Comparative $16 \mathrm{~S}$ rDNA sequence analysis of some alkaliphilic bacilli and the establishment of a sixth rRNA group within the genus Bacillus. FEMS Microbiol Lett 117, 61-66.

Nielsen, P., Fritze, D. \& Priest, F. G. (1995). Phenetic diversity of alkaliphilic Bacillus strains: proposal for nine new species. Microbiology 141, 1745-1761.

Saitou, N. \& Nei, M. (1987). The neighbour-joining method: a new method for reconstructing phylogenetic trees. Mol Biol Evol 4, 406-425.

Schleifer, K. H. (1985). Analysis of the chemical composition and primary structure of murein. Methods Microbiol 18, 123-156.

Schleifer, K. H. \& Kandler, O. (1972). Peptidoglycan types of bacterial cell walls and their taxonomic implications. Bacteriol Rev 36, 407-477.

Vargas, V. A., Delgado, O. D., Hatti-Kaul, R. \& Mattiasson, B. (2004). Lipase-producing microorganisms from a Kenyan alkaline soda lake. Biotechnol Lett 26, 81-86.

Wayne, L. G., Brenner, D. J., Colwell, R. R. \& 9 other authors (1987). International Committee on Systematic Bacteriology. Report of the ad hoc committee on reconciliation of approaches to bacterial systematics. Int J Syst Bacteriol 37, 463-464.

Weisburg, W. G., Barns, S. M., Pelletier, D. A. \& Lane, D. J. (1991). $16 \mathrm{~S}$ ribosomal DNA amplification for phylogenetic study. J Bacteriol 173, 697-703. 